\title{
Species-specific probe, based on $18 S$ rDNA sequence, could be used for identification of the mucilage producer microalga Gonyaulax fragilis (Dinophyta)
}

\author{
M. Riccardi · F. Guerrini · F. Tinti · L. Boni · \\ R. Pistocchi
}

Published online: 15 June 2007

(C) Springer Science+Business Media B.V. 2007

\section{Erratum to: Hydrobiologia 580:259-263 \\ DOI 10.1007/s10750-006-0446-z}

The authors of this article were printed in the wrong order. The correct order is given here. The publishers apologise for this error.

The online version of the original article can be found at http:// dx.doi.org/10.1007/s10750-006-0446-z

Guest editors: G. Relini \& J. Ryland

Biodiversity in enclosed seas, and artificial marine habitats

M. Riccardi $(\varangle) \cdot$ F. Guerrini · F. Tinti · L. Boni ·

R. Pistocchi

Centro Interdipartimentale di Ricerche sulle Scienze Ambientali (CIRSA), Alma Mater Studiorum University of Bologna, Via S. Alberto 163, 48100 Ravenna, Italy

e-mail: manuela.riccardi@unibo.it 